\title{
Bakar u eneolitičkim kulturnim zajednicama Bosne i Hercegovine Copper in eneolithic communities of Bosnia and Hercegovina
}

\author{
Andrijana Pravidur \\ Zemaljski muzej Bosne i Hercegovine \\ National Museum of Bosnia and Hercegovina \\ Sarajevo \\ andrijana.pravidur@gmail.com
}

DOI: $10.17234 / 9789531758185-17$

Upotreba bakra i razvoj metalurgije na susjednim zemljopisnim područijma imao je odraz na današnje područje Bosne i Hercegovine kroz društvena kretanja i kontakte, a čiji je impuls između ostalog uvjetovan i potragom za rudnim sirovinama. Stoga se na području današnje Bosne i Hercegovine proces metalizacije razvija u okviru metalurške tradicije onih društvenih zajednica koje s vremenom zauzimaju i naseljavaju ovo područje. Prvi metalni (bakreni) predmeti koji su cirkulirali širim regionalnim područjem kroz razmjenu, trgovinu i društvena kretanja pronašli su se kao rijetki i slučajni nalazi i na području Bosne i Hercegovine. Oni najraniji svjedoče o samim početcima upotrebe i poznavanja metala te njegovu postupnom uvođenju u materijalnu kulturu prapovijesnih zajednica. Najranijem poznavanju ne samo metala već i metalnih izrađevina svjedoče nalazi iz srednje Bosne u obliku sitnih izrađevina - nakita (bakrenih perli), koji su svoje mjesto u okviru neolitičkih kulturnih zajednica na lokalitetima Obre I, Obre II i Butmir (Benac 1979: 371, 374) pronašli vjerojatno kao uvozni materijal posredovanjem razmjene i trgovine. Najranija zabilježena pojava upotrebe ili poznavanja bakra na području Bosne i Hercegovine potječe s lokaliteta Obre I u sloju s materijalom koji upućuje na ranu fazu u razvoju lokalne kakanjske kulture (Gimbutas 1974: 11; Sterud \& Sterud 1974: 258) gdje fragment malahitne perle, zabilježen u kontekstu kuće pokazuje vrlo rano poznavanje metala ovoga područja iz sredine 6 . milenija pr. Kr. (Gimbutas 1974: 22, 358). Sitni bakreni nalazi i fragmenti metala prepoznati su i zabilježeni i na lokalitetu Obre
The use of copper and the development of metallurgy in the neighboring geographical regions reflected on today's territory of Bosnia and Herzegovina through social movement and contacts that were, among other things, spurred by the search for sources of ore. Hence, in today's Bosnia and Herzegovina, the process of metallization developed within the framework of the metallurgical tradition of social communities that, in time, conquered and inhabited this area. The first metal (copper) finds that circulated in the wider region through exchange, trade and social movements were also recorded on the territory of Bosnia and Herzegovina as chance and individual finds. The earliest finds attest to the very beginnings of using and working with metal, and its gradual influx into the material culture of prehistoric communities. The earliest evidence of using not only metals, but also metal artifacts, in central Bosnia appears in the form of small artifacts - jewelry (copper beads) that found their place within the scope of Neolithic cultural communities at the sites Obre I, Obre II and Butmir (Benac 1979: 371, 374), probably as material imported through trade and exchange. The earliest recorded use of copper in Bosnia and Herzegovina originates from the site of Obre I, and was discovered in a layer that also contained material ascribed to the early phases of the local Kakanj culture (Gimbutas 1974: 11; Sterud \& Sterud 1974: 258). The fragment of a malachite bead, recorded within a house, indicates a very early use of metal in this area, dated to the $6^{\text {th }}$ millennium BC (Gimbutas 1974: 22, 358). At the same time, tiny copper finds 


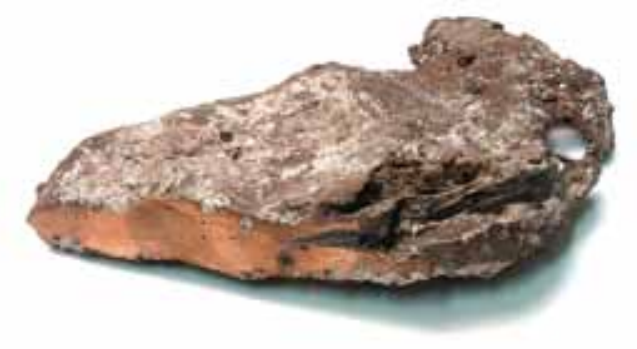

Slika / Figure 1. Ploča samorodnog bakra, Vareš, BiH / A plate of native copper, Vareš, B\&H (prema / after: Operta 2009).

II, u slojevima kasne butmirske kulture na što je sporadično ukazao Benac (1971: 267). Većina bakrenih nalaza iz ovoga perioda rezultat je proizvodnje koja se temelji na tehnici hladnog kovanja, koja je duboko utemeljena u tradiciji neolitičke, odnosno litičke industrije pa je ova najranija bakrena proizvodnja rezultat jednostavnog modeliranja sitnih, odnosno ornamentalnih predmeta.

$S$ vremenom kada metalurška aktivnost počinje poprimati sve veću važnost u ekonomskom i gospodarskom aspektu, a metalurške zajednice migriraju u potrazi za rudnom sirovinom, počela se razvijati aktivnija samostalna i lokalna proizvodnja šireg opsega o čemu svjedoče raznovrsni metalurški nalazi na našem području. Na području istočne Bosne koja u kulturnom smislu pripada istočnobosanskoj varijanti vinčanske kulture već se odvijala metalurška aktivnost koju vezujemo uz naselja Gornje i Donje Tuzle i to u mlađim, eneolitičkim fazama. U stratumima III i II koji pripadaju mlađim slojevima vinčanske kulture u Gornjoj Tuzli zabilježeni metalni i arheometalurški nalazi svjedoče o ranom razvoju i poznavanju metalurške aktivnosti na području Bosne i Hercegovine (Čović 1961; Glumac \& Todd 1987; 1991: 11-12, sl. 4; Radivojević et al. 2010: 2778; Radivojević 2015; Radivojević \& Rehren 2016; Radivojević \& Grujić 2017). Ova dva stratuma u cjelokupnoj stratigrafiji lokaliteta, upućuju na vrlo bogat i raznovrstan kulturni materijal što je, kako se čini, rezultat snažnog ekonomskog razvoja naselja u ovom periodu, kada je naselje najvjerojatnije obuhvaćalo i najveću površinu te doživjelo svoj procvat (Čović 1961: 94). Nalazi s ovoga lokaliteta povezani su s procesima proizvodnje u okviru industrije bakra, a kompleksnost metalurške aktivnosti ogleda se u različitoj vrsti arheometalurškog materijala. Stoga se metalurška djelatnost područja istočne Bosne odvijala and metal fragments were discovered and recorded at the Obre II site, in the layers of the late Butmir culture, as sporadically mentioned by Benac (1971: 267). Most copper finds from this period are the result of production, based on the technique of cold casting that was well-founded in the tradition of the Neolithic, i.e. stone industry, so that this earliest copper production was the result of the simple modeling of very small, ornamental, objects.

In time, as the metallurgical activities started to gain importance in an economic sense, and metallurgical communities migrated in search of raw ores, a more active, independent and local widerrange production started to develop, as attested to by various metallurgical finds from the region. In eastern Bosnia, which can, culturally, be ascribed to the eastern Bosnian variant of the Vinča culture, already entailed metallurgical activities that can be connected with the settlements at Gornja and Donja Tuzla in the younger, Eneolithic phases. Strata III and II at Gornja Tuzla, ascribed to the younger layers of the Vinča culture, yielded metal and archaeological metal finds that speak in favor of an early development and use of metallurgical activities in Bosnia and Herzegovina (Čović 1961; Glumac \& Todd 1987; 1991: 11-12, fig. 4; Radivojević et al. 2010: 2778; Radivojević 2015; Radivojević \& Rehren 2016; Radivojević \& Grujić 2017). Out of the entire stratigraphy of the site, these two strata point to a very rich and diverse cultural material that, as it seems, resulted from a strong economic growth of the settlement in this period, when the settlement probably covered the largest area and was prosperous (Čović 1961: 94). The finds from this site are connected to the production processes of copper industry, and the complexity of metallurgical activities can be seen through the different kinds of archaeological material made of metal. Therefore, the metal- 
u tradiciji vinčanske kulture, samostalno i na lokalnoj razini, u opsegu koji je zadovoljavao potrebe za bakrom i bakrenim izrađevinama u vremenu 4400 pr. Kr. (Radivojević \& Rehren 2016).

U razmatranju prapovijesnog rudarstva i talioničarstva na području Bosne i Hercgeovine Vejsil Ćurčić prvi upućuje na značenje nalaza iz Donje Tuzle, posudice, mlađe faze vinčanske kulture, a na čijem su dnu pronađeni ostaci mineralne metalične mase, što je rezultat pokušaja topljenja komada olovnog sjajnika-galenita (Ćurčić 1908: 82, T. I: 15; Čović 1961: 98, T. X: 13-15, sl. 16; Benac 1964: 95, 133; Čović 1984). Izdvajanje male količine olovnog oksida i sumpora zbog nedovoljno dostatne temperature za potpuno topljenje metala, Ćurčić je protumačio kao eksperimentalni i najraniji pokušaj dobivanja olova (Ćurčić 1908: 84; 1930: 408). Ipak, nalazi bakrenog minerala malahita iz Donje Tuzle mogu sugerirati na još stariju upotrebu ruda i moguću metaluršku djelatnost u okviru starije faze vinčanske kulture na području Bosne i Hercegovine.

Sustavnija istraživanja badenske kulture rezultirala su i saznanjem da je ova kultura pored bakrenih nalaza poznavala i primjenjivala metaluršku, ljevačku djelatnost koja se koristila sulfidnom bakrenom rudom. Metalurški centri badenske kulture na području Brodskog Posavlja, Saloš u Donjoj Vrbi i Okukalj kod Donje Bebrine, na osnovi arheometa- lurgical activities in eastern Bosnia occurred within the tradition of the Vinča culture, individually and locally, and to an extent that satisfied the needs for copper and copper artifacts around 4400 BC (Radivojević \& Rehren 2016).

When studying prehistoric mining and smelting in Bosnia and Herzegovina, Vejsil Ćurčić was the first to pint out the significance of the finds from Donja Tuzla - small vessels of the Vinča culture with traces of mineral metallic mass at their base, created as a result of an attempt to melt a piece of a lead sulfide - galena (Ćurčić 1908: 82, PI. I: 15; Čović 1961: 98, Pl. X: 13-15, fig. 16; Benac 1964: 95, 133; Čović 1984). Čurčić described the extraction of a small amount of lead oxide and sulfur, due to temperatures that were insufficiently high to fully melt the metal, as an experimental, and the earliest attempt to obtain lead (Ćurčić 1908: 84; 1930: 408). However, the finds of the copper mineral malachite from Donja Tuzla indicate an even earlier use of ores, and possible metallurgical activities within the context of the older phase of the Vinča culture in Bosnia and Herzegovina.

The more systematic study of the Baden culture revealed that this culture, in addition to copper finds, also knew and used metallurgical, smelting, activities based on the use of sulfide copper ore. The archaeological material made of metal from the metallurgical centers of the Baden culture in the Brod-

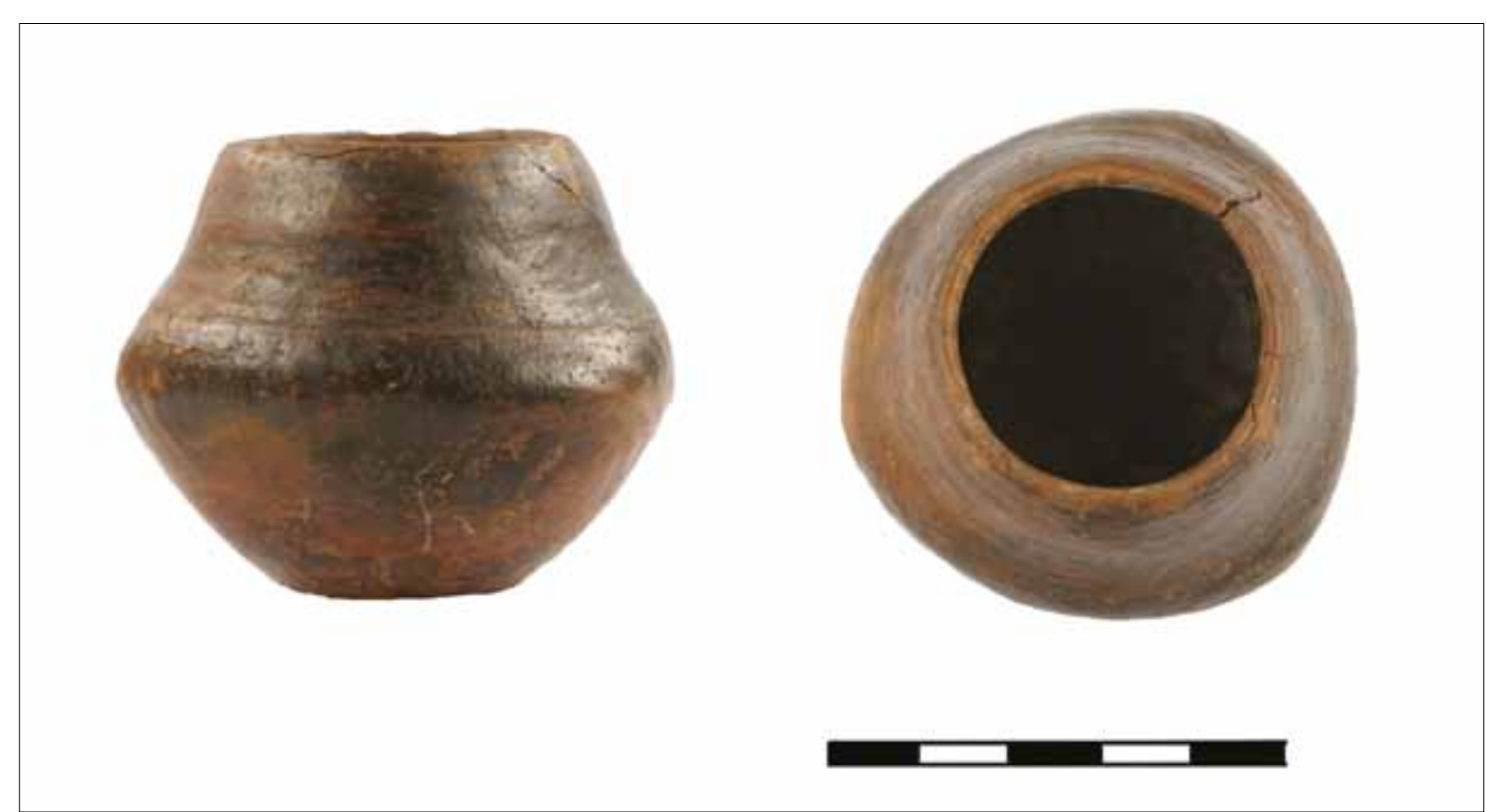




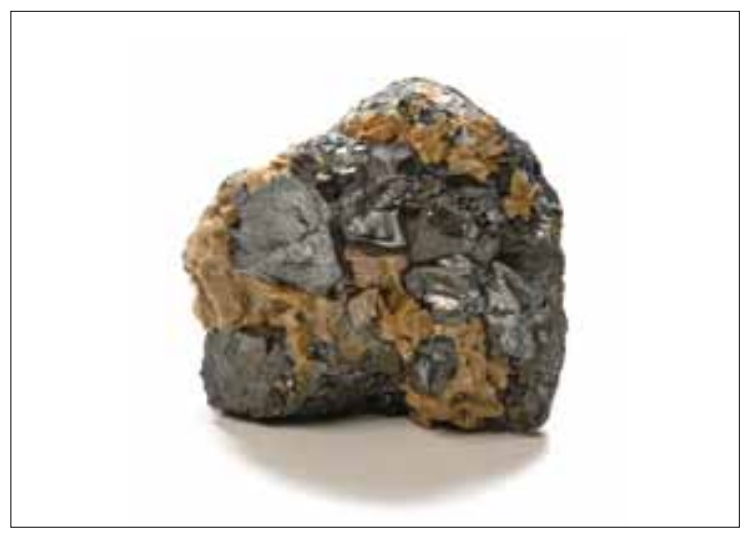

Slika / Figure 3. Tetraedrit sa sideritom, Maškara, Gornji Vakuf, BiH / Tetrahedrite with siderite, Maškara, Gornji Vakuf, B\&H (prema / after: Operta 2009).

lurškog materijala pokazuju vrlo razvijenu metalurgiju bakra koja je zbog potrebe za sulfidnim bakrenim mineralima najvjerojatnije bila i prostorno organizirana na širem zemljopisnom području (Lozuk 1995: 55; Durman 2000; 2006: 30). U tom smislu je područje Bosne i Hercegovine koje obiluje sulfidnom rudom vjerojatno bilo primarno i najbliže izvorište ovoga bakrenog minerala za potrebe badenske metalurgije na području Slavonije i šireg njezinog područja. Putovi koji su vodili do rudnih izvorišta na području Bosne, osobito riječne doline Vrbasa i Bosne, predstavljaju najznačajnije komunikacijske smjerove sa srednjobosanskim rudnim područjem o čemu svjedoče i pozicije badenskih lokaliteta na području Bosne i Hercegovine.

Tijekom probnih arheoloških iskopavanja 1958. i sustavnih 1960. godine na lokalitetu Pivnica kod Ožaka definirana je kostolačka kultura u okviru starijeg stratuma (Benac 1962: 22) gdje je u sondi 3 zabilježena i veća kostolačka kuća s dvije faze izgradnje. Iz starije faze kuće pored centralnog ognjišta zabilježena je jama (C) koja je služila kao ostava ili otpadna jama. Pored velike količine grube i fine keramike u jami je zabilježena i jedna bakrena igla (kako ju Benac definira) četvrtastog, u gornjem dijelu proširenog presjeka s trnom (Benac 1962: 24, 27, T. X: 11), a radi se o bakrenom šilu kakva su poznata is drugih lokaliteta kostolačke kulture. Osim ovoga nalaza, tijekom iskopavanja 1960. godine zabilježeno je još jedno cjelovito i nekoliko ulomaka bakrenih šila istog tipa (Benac 1962: 27). Ovi nalazi s područja Bosne i Hercegovine mogu se usporediti s onima zabilježenim na kasnobakrenodobnom naselju Đakovo - Franjevac (Balen 2011: 121 , kat. $1,3,5)$ te u kostolačkom naselju u Gomolavi (Petrović \& Jovanović 2002: 281-284). sko Posavlje region, Saloš in Donja Vrba and Okukalj near Donja Bebrina, point to a well-developed copper metallurgy that was, due to the need for sulfide copper minerals, most probably spatially organized over a wider geographical region (Lozuk 1995: 55; Durman 2000; 2006: 30). In that sense, the territory of Bosnia and Herzegovina, which is abundant in sulfide ore, was probably the primary and the closest source of this copper mineral used in the Baden culture metallurgy in Slavonia and the wider area. The routes that connected the sources of ore in Bosnia, especially in the Vrbas and Bosna River valleys, and the mining regions in central Bosnia, were the most significant communication paths, as attested to by the position of sites of the Baden culture in Bosnia and Herzegovina.

The 1958 test, and the 1960 systematic excavations of the Pivnica near Odžak site yielded finds of the Kostolac culture (Benac 1962: 22), when a larger house of the Kostolac culture with two phases of construction was found in trench 3 . The older phase of the house yielded a pit (C), situated next to the central hearth, that was used as a pantry or a waste pit. In addition to the large amounts of coarse and fine pottery, the pit also yielded a copper needle (as defined by Benac) with a square cross-section on the upper part, and a shaft (Benac 1962: 24, 27, PI. $X: 11)$. However, it is a copper awl the likes of which have been discovered at other sites of the Kostolac culture. In addition to this find, the 1969 excavations yielded another complete and several fragmented copper awls of the same type (Benac 1962: 27). These finds from Bosnia and Herzegovina can be compared to those recorded at the Late Eneolithic site of Đakovo-Franjevac (Balen 2011: 121, cat. 1, 3, 5) and from the settlement of the Kostolac culture at Gomolava (Petrović \& Jovanović 2002: 281-284).

By far a more tangible record of metallurgical activities in Bosnia and Herzegovina can be seen in the material of the Vučedol culture. When this cultural community stabilized and produced finds that can definitively be described as metallurgical produce, four sites in Bosnia and Herzegovina (the Zecovi hillfort near Prijedor, Debelo Brdo near Sarajevo, the Alihodže hillfort in the Bila valley, Velika gradina in Varvara) reveal the development and degree of local copper metallurgy. Although the first finds of the Vučedol cultural group had been discovered already at the end of the $19^{\text {th }}$ century at Debelo Brdo, only the more extensive excavations conducted after those at the Hrustovača cave in 1939 (Benac 1948; 1950; 1964: 136-147), would point 
Daleko konkretnija dokumentiranost metalurške djelatnosti na tlu Bosne i Hercegovine dolazi s materijalnom ostavštinom nosilaca vučedolske kulture. Stabilizacijom ove kulturne zajednice te nalazima koji se sasvim pouzdano mogu odrediti u skupinu metalurških objekata, na četiri lokaliteta u Bosni i Hercegovini (Gradina Zecovi kod Prijedora, Debelo Brdo kod Sarajeva, Gradina Alihodže u dolini Bile, Velika gradina u Varvari) može se pratiti razvoj i stupanj domaće bakrene metalurške industrije. Premda su prvi nalazi vučedolske kulturne grupe otkriveni već krajem 19. stoljeća na DebeIom Brdu, tek će nešto opsežnija istraživanja koja su uslijedila nakon iskopavanja pećine Hrustovača 1939. godine (Benac 1948; 1950; 1964: 136-147) potvrditi značenje ove kulturne skupine u okviru metalurške industrije eneolitičkog razdoblja Bosne i Hercegovine. Već poznavanje metalurške radionice na Vučedolu (Schmidt 1945: 206), i objavljivanje metalurškog pribora i bakrenih nalaza iz Ljubljanskog barja (Korošec \& Korošec 1969: 20-21) značajnije su potaknuli izučavanje metalurške djelatnosti grupe što će se s vremenom odraziti i na područje ove kulture južno od Save. Od 70-tih godina 20. stoljeća polako će se neki stariji, dotad nedeterminirani nalazi revidirati i pouzdano opredijeliti skupini metalurških objekata, čime se povećava broj specifičnih metalurških artefakata pa im se i sasvim konkretno pronalazi mjesto $i$ funkucija u fundusu arheološkog materijala (Čović 1976; Durman 1983; 1988; 2006; Žeravica 1993). Najznačajniji nalazi koji konkretno upućuju na metaluršku djelatnost pa i na moguće metalurške centre ove kulturne zajednice u Bosni i Hercegovini već su poznati i više puta interpretirani s gradina u Zecovima kod Prijedora, Debelog brda u Sarajevu, Alihodža kod Travnika i Velike gradine u Varvari. Premda dosadašnji poznati nalazi vezani uz metalurgiju vučedolske kulture na području Bosne i Hercegovine i nisu osobito brojni, tehnološke karakteristike metalurškog materijala, posebno kada je riječ o nalazima kalupa ili sopalja, sasvim jasno ukazuju na stupanj razvoja metalurgije bakra te domete bakrene industrije koja se odvijala u tradiciji vučedolske kulturne zajednice.

Najjužnije nalazište vučedolske kulture na području Bosne i Hercegovine poznato je na Debelom brdu u Sarajevu. Metalurški nalazi bili su poznati još S kraja 19. stoljeća i objavljeni u izvještajima $F$. Fiale (1894: 107-124, sl. 2, T. VIII: 9, 11, 12) koji konstatira da je na Debelom brdu postojala raznovrsna i živa zanatska djelatnost $i$ to ne samo u željezno to the significance of this cultural group when it came to the metallurgy of the Eneolithic period in Bosnia and Herzegovina. The previously discovered metallurgical workshop from Vučedol (Schmidt 1945: 206), and the publication of metallurgical equipment and copper finds from Ljubljansko barje (Korošec \& Korošec 1969: 20-21), had a more significant impact on the study of the group's metallurgical activities that were, in due time, reflected on the territory occupied by this culture south of the Sava River. Starting from the 1970s, some older, but previously undetermined finds have been reevaluated and definitively ascribed to the group of metallurgical objects, thereby increasing the number of specific metallurgical artifacts that found their place and function in the archaeological material (Čović 1976; Durman 1983; 1988; 2006; Žeravica 1993). The most significant finds that definitively point to metallurgical activities, as well as to possible metallurgical centers of this cultural group in Bosnia and Herzegovina, are well-known, and were recorded at the following sites: the Zecovi hillfort near Prijedor, Debelo brdo in Sarajevo, Alihodža near Travnik, and Velika gradina in Varvara. Although the previously known finds related to the metallurgy of the Vučedol culture in Bosnia and Herzegovina are not numerous, the technological characteristics of the metallurgical material, especially in the case of

Slika / Figure 4. Nalazi kalupa i sopalja s lokaliteta Alihodže i Varvara, Zemaljski muzej BiH / Molds and nozzles of bellows from Alihodže and Varvara, National Museum of B\&H (prema / after: Čović 1977; Žeravica 1993)

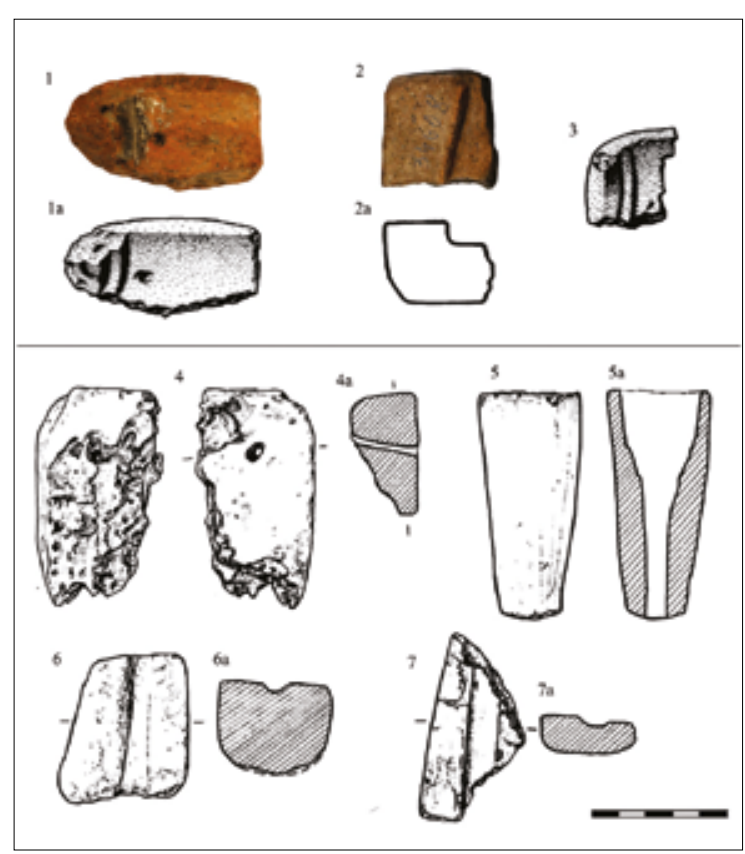


doba, već i ranije (Fiala 1894: 124-125). Iz ovog naseobinskog kompleksa potječe nešto veći, ali raznolikiji broj metalurškog pribora na osnovi kojega se može sagledati i nešto konkretnija slika o bakrenoj industriji koja se odvijala u okviru južnobosanskog tipa vučedolskog kulturnog kompleksa. Nalazi kalupa i metalurškog pribora - sopalja u naselju ukazuju na metaluršku djelatnost koja se očito odvijala kroz sve neophodne procese bakrene industrije, a koja podrazumijeva obradu rudne sirovine u naselju i ljevačku djelatnost do konačnog proizvoda. Ovakav istovjetni obrazac metalurške aktivnosti poznat je i s gradine Zecovi u Prijedoru. Posebno se to odnosi na nalaze keramičkih nastavaka za puhaljke - sopalje, koji su s dva primjerka zastupljeni i u naseobinskom lokalitetu Debelo brdo. Upravo specifičnost ovih nalaza omogućuje rekonstrukciju i stupanj metalurške aktivnosti, odnosno načina termalne obrade bakrene mineralne sirovine koja se i na Debelom brdu kao i na Zecovima odvijala u otvorenim ognjištima. Repertoar nalaza kalupa s Debeloga brda ukazuje i na raznoliku proizvodnju bakrenih predmeta, a najčešći su kalupi za sjekire $s$ jednom oštricom i cilindričnim produžetkom za nasad drška (Fiala 1894: 118, sl. 12; Čović 1976: 109, T. II: 1-3; Durman 1983: 32; Žeravica 1993: 27, T. 8: 84-86) koje su i najčešći repertoar ostava.

Najveći broj bakrenih alatki s područja Bosne i Hercegovine u okviru vučedolskog kulturnog kompleksa pripada slučajnim ili pojedinačnim nalazima te nalazima iz ostava. Serijska proizvodnja i tehnika lijevanja u dvodijelne kalupe metalurška je inovacija koja se primjenjivala i na prostoru vučedolskoga kulturnog kompleksa s kojom započinje i izrada novog tipa oruđa - sjekira sa cilindričnim produžetkom za nasad drška i jednom oštricom, odnosno sjekire tipa Kozarac. Redovito se javljaju u ostavama ili kao pojedinačni, slučajni nalazi. Iz dosad poznatih ostava, sjekire ovoga tipa mogu se javljati zajedno, odnosno na području Bosne i Hercegovine isključivo s plosnatim lepezastim sjekirama - tipa Griča. Sjekire s jednom oštricom i cilindričnim produžetkom za nasad drška - tipa Kozarac (Žeravica 1993: 24-26) s područja Bosne i Hercegovine poznate su iz ostava: Kozarac kod Prijedora (Truhelka 1907), Griča kod Mrkonjić Grada (Truhelka 1906; Žeravica 1993: 22, 27), Vranovići i Lohinja kod Gračanice (Čović 1957; Durman 1983: 41; Žeravica 1993: 28). Nalazi ostava s većim brojem istovjetnih bakrenih predmeta, najčešće sjekira, mogu sugerirati na robu namijenjenu prodaji ili molds or the nozzles of bellows, clearly point to the degree of development of copper metallurgy, and the achievements of the copper industry that took place within the tradition of the Vučedol cultural group. The southernmost site of the Vučedol culture in Bosnia and Herzegovina was recorded at Debelo brdo in Sarajevo. Metallurgical finds had been known from the end of the $19^{\text {th }}$ century, and were published in F. Fiala's reports (1894: 107-124, fig. 2, PI. VIII: 9, 11, 12), wherein he concluded that Debelo Brdo was a place where a diverse and lively crafting activities were happening, and not only during the Iron Age, but also prior to it (Fiala 1894: 124-125). This settlement complex yielded a larger, but more versatile, number of metallurgical equipment that can serve as the basis for the study of a more tangible image of copper industry that took place in the context of the southern Bosnian type of the Vučedol cultural complex. Finds of molds and metallurgical equipment, such as nozzles of bellows, suggest metallurgical activities that evidently covered all of the necessary processes of copper industry, including ore processing within the settlement, and smelting activities that led to the creation of the final product. The same pattern of metallurgical activities was also recorded at the Zecovi hillfort in Prijedor, especially when discussing the ceramic endings of bellows - nozzles, two of which were found at the settlement of Debelo brdo. Precisely the specificity of these finds allows for the reconstruction of the degree of metallurgical activities, i.e. the ways in which copper raw materials were thermally processed, noting that it took place in open hearths at both Debelo Brdo and Zecovi. The repertoire of mold from Debelo Brdo also reveals the versatile production of copper objects, and the most common molds were used to make axes with a single blade and a cylindrical protrusion for hafting (Fiala 1894: 118, fig. 12; Čović 1976: 109, PI. II: 1-3; Durman 1983: 32; Žeravica 1993: 27, PI. 8: 84-86), which are also the most common find in hoards.

Most copper tools from Bosnia and Herzegovina that can be ascribed to the Vučedol cultural complex are chance and individual finds, or were parts of hoards. Serial production and the technique of casting in bipartite molds are metallurgical innovations that were applied on the territory of the Vučedol cultural complex, and that also led to the production of a new type of tool - axes with a cylindrical protrusion for hafting and a single blade, i.e. the Kozarac type of axe. These are a common find in hoards, as well as a common individual, chance 


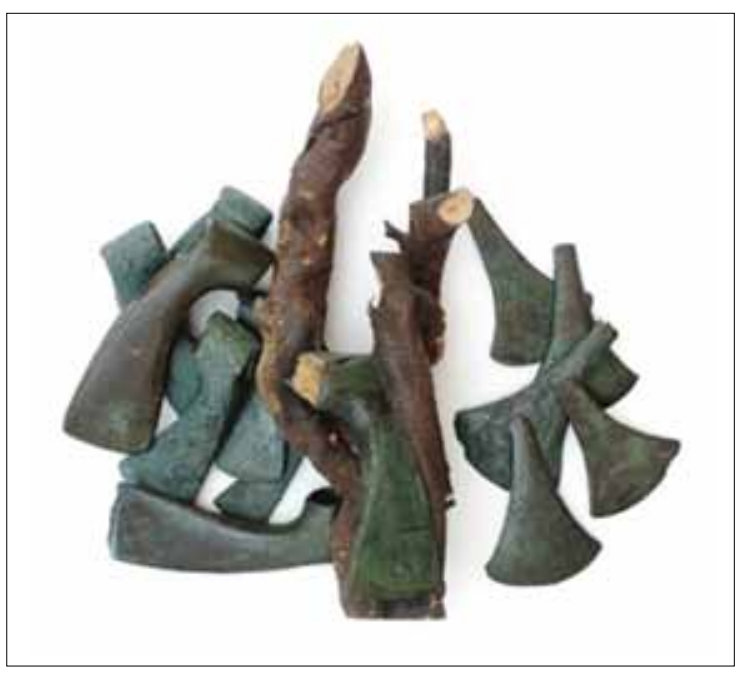

Slika / Figure 5. Ostava Griča kod Mrkonjić grada / The Griča hoard near Mrkonjić grad (foto / photo: A. Šahbaz).

način prenošenja sirovina iz područja ležišta ruda u krajeve gdje ležišta nije bilo, a gdje je postojala potreba za bakrenim izrađevinama (Težak-Gregl 2006: 38). Tako se sve više pojava ovakvih tipova sjekira u ostavama može sagledati i u funkciji ingota ili poluproizvoda što je uvelike olakšavalo transport metalne sirovine do udaljenih radioničkih centara.

Poznavanje metalurške aktivnosti vučedolske kulture na području Bosne i Hercegovine odraz je dosad poznatog i analiziranog metalurškog materijala, koji je rezultat i tek djelomična slika stanja istraženosti ove kulture na našem području. Premda ne toliko brojni, ovi nalazi s područja Bosne i Hercegovine ipak pokazuju stupanj razvoja metalurške aktivnosti koja je bila u skladu s općom metalurškom slikom vučedolskoga kulturnog kompleksa. Potraga za novim rudnim izvorima pokrenula je migraciju ove kulture upravo radi održavanja metalurške tradicije koja je predstavljala jednu od važnijih grana ekonomske strukture. S druge strane tehnološki napredak u metalurgiji vučedolske kulture rezultirao je i potrebom za većom količnom metala što je zahtijevalo pronalazak i eksploataciju novih ležišta koja osiguravaju dovoljnu količinu rudne sirovine, s obzirom na to da je serijska proizvodnja ubrzala i kvantitativno povećala izradu identičnih bakrenih alatki. Ove novine koje je predvodila sve naprednija metalurška tehnologija u kasnoj su fazi vučedolske kulture rezultirale i pomicanjem metalurških i radioničkih središta bakrene industrije koja su se na području Bosne i Hercegovine koncentrirala uglavnom u blizini rudnih izvora i riječnih komunikacija. find. Based on the hoards discovered so far, this type of axe can appear, that is, in Bosnia and Herzegovina, exclusively alongside flat trapezoidal axes of the Grič type. Axes with a single blade and a cylindrical protrusion for hafting - the Kozarac type (Žeravica 1993: 24-26) have been found in the following hoards in Bosnia and Herzegovina: Kozarac near Prijedor (Truhelka 1907), Grič near Mrkonjić Grad (Truhelka 1906; Žeravica 1993: 22, 27), Vranovići and Lohinja near Gračanica (Čović 1957; Durman 1983: 41; Žeravica 1993: 28). Hoards with a large number of the same kind of copper find, most often axes, can indicate goods that were prepared for trade, or the modes of transporting raw materials from the mines to places where there were no raw materials, and where copper artifacts were required (TežakGregl 2006: 38). Hence, the increasing emergence of these types of axes indicates that they could be interpreted as ingots or semi-products that would greatly alleviate the transport of metals to the distant workshop centers.

The knowledge on the metallurgical activities of the Vučedol culture in Bosnia and Herzegovina is a reflection of the published and analyzed metallurgical material, which is the result, and only a partial image, of the state of research conducted on this culture in the region. Although not numerous, the finds from Bosnia and Herzegovina indicate the developmental degree of metallurgical activities that were in line with the general metallurgical framework of the Vučedol cultural complex. Searching for new sources of ore sparked a migration of this culture precisely in order to preserve the metallurgical tradition that was one of the most important parts of their economic structure. On the other hand, the technological advances in the metallurgy of the Vučedol culture resulted in an increased need for metals, which, in turn, required the discovery and exploitation of new sources of raw materials that would provide sufficient amount of ore, especially because serial production sped up and increased the production of identical copper tools. During the late phase of the Vučedol culture, these novelties, led by the increasingly advanced metallurgical technology, resulted in a shift of metallurgical and workshop centers that were, in Bosnia and Herzegovina, mostly concentrated in the vicinity of ore sources and river communication routes. 
Literatura / Bibliography

Balen J. 2011, Dakovo-Franjevac, kasno bakrenodobno naselje/ Đakovo-Franjevac, Late eneolithic settlement, Katalozi i Monografije 7, Arheološki muzej u Zagrebu, Zagreb.

Benac A. 1948, Završna istraživanja u pećini Hrustovači, Glasnik Zemaljskog muzeja u Sarajevu n.s. III, Sarajevo, 5-42.

Benac A. 1962, Pivnica kod Odžaka i neki problemi kostolačke kulture, Glasnik Zemaljskog muzeja u Sarajevu, n. s. A. XVII, Sarajevo, 21-40.

Benac A. 1964, Studije o kamenom i bakrenom dobu u sjeverozapadnom Balkanu, Veselin Masleša, Sarajevo.

Benac A. 1971, Sjeverozapadni Balkan na prelazu iz neolitskog u metalno doba, Radovi Filozofskog fakulteta u Sarajevu VI, Sarajevo (1970-1971), 265-272.

Benac A. 1979, Prelazna zona, in: A. Benac \& M. Garašanin (eds.), Praistorija Jugoslavenskih Zemalja II - Neolitsko doba, Akademija nauka i umjetnosti Bosne i Hercegovine, Centar za balkanološka ispitivanja, Sarajevo, 363-470.

Čović B. 1957, Nekoliko manjih preistorijskih nalaza iz Bosne i Hercegovine, Glasnik Zemaljskog muzeja u Sarajevu, n. S. A. XII, Sarajevo, 241-255.

Čović B. 1961, Rezultati sondiranja na prehistorijskom naselju u Gornjoj Tuzli, Glasnik Zemaljskog muzeja u Sarajevu n. S. A. XV-XVI, Sarajevo (19601961), 79139.

Čović B. 1976, Metalurška djelatnost vučedolske grupe u Bosni, Godišnjak XIII/ 11, Centar za balkanološka istraživanja, Sarajevo, 105-115.

Čović B., 1977, Velika gradina u Varvari - I dio (slojevi eneolita, ranog i srednjeg bronzanog doba), Glasnik Zemaljskog muzeja Bosne i Hercegovine u Sarajevu n. S. A. XXXII, Sarajevo (1978), 5-173.

Čović B. 1984, Praistorijsko rudarstvo i metalurgija u Bosni i Hercegovini - stanje i problemi istraživanja / Das prähistorische Bergbauwesen und die Metalurgie in Bosnien und der Herzegowina, Godišnjak XXII/20, Centar za balkanološka ispitivanja, Akademija nauka i umjetnosti Bosne i Hercegovine, Sarajevo, 111-145.

Ćurčić V. 1908, Prilozi poznavanju prehistorijskog rudarstva i talioničarstva brončanog doba u Bosni i Hercegovini, Glasnik Zemaljskog muzeja u Bosni i Hercegovini XX/ 1, Sarajevo, 77-90.

Ćurčić V. 1930, Historija rudarstva i topioničarstva u Bosni i Hercegovini, Rudarski i topioničarski Vesnik 9, Beograd, 317-334.
Durman A. 1983, Metalurgija vučedolskog kulturnog kompleksa, Opuscula Archaeologica 8, Zagreb.

Durman A. 1988, Metal u vučedolskom kulturnom kompleksu / Metal in the Vučedol Cultural Complex, in: Vučedol treće tisuljeće p.n.e/ Vučedol three thousand years b.c., Katalog izložbe, Muzejski prostor Zagreb, 32-39.

Durman A. 2000, Počeci metalurgije na Brodskom području, Zbornik radova sa znanstvenog skupa 0 Slavonskom Brodu, Slavonski Brod u povodu 750. Obljetnice prvoga pisanog spomena imena Broda, Slavonski Brod, 91-102.

Durman A. 2006, Simbol boga i kralja, in: Simbol boga i kalja-prvi europski vladari / Symbol of God and King-the first European rulers, Katalog izložbe, Galerija Klovićevi dvori Zagreb, 11-86.

Fiala F. 1894, Jedna prehistorička naseobina na Debelom Brdu kod Sarajeva, Glasnik Zemaljskog muzeja u Bosni i Hercegovini VI/ 1, Sarajevo, 107-140.

Gimbutas M. 1974, Chronology of Obre I and Obre II, Wissenschaftliche Mitteilungen des Bosnisch-Herzegowinischen Landesmuseums IV, Sarajevo, 15-35.

Glumax P. \& Todd J. 1987, New Evidence for the use of Lead in Prehistoric South East Europe, Archeomaterials 2, 29-37.

Glumac P. \& Todd J. 1991, Early Metallurgy in Southeast Europe: the Evidence for Production, in: P. Glumac (ed.), Recent Trends in Archaeometallurgical Research, MASCA Research Papers in Science i Archaeology, vol. 8, part I, Philadelphia, University of Pennsylvania, 8-19.

Korošec P. \& Korošec J. 1969, Najdbe s količarskih naselbin pri Igu na Ljubljanskom barju/ Fundgut der Pfahlbausiedlungen bei Ig am Laibacher Moor, Arheološki katalogi Slovenije III, Ljubljana.

Lozuk J. 1995, A problem of the Baden group Metallurgy at the Site of Salos-Donja Vrba near Slavonski Brod, in: B. Jovanović (ed.), Ancient mining and Metallurgy in Southeast Europe, International Symposium, D. Milanovac 1990, Bor-Belgrade, 55-58.

Operta M. 2009, Mineralogija, knjiga I, Zenica.

Petrović J. \& Jovanović B. 2002, Gomolava - naselje kasnog eneolita, Muzej Vojvodine-Arheološki Institut, Novi Sad-Beograd.

Radivojević, M., Rehren, T., Pernicka, E., Šljivar, D., Brauns, M., Borić, D. 2010, On the origins of extractive metallurgy: new evidence from Europe, Journal of Archaeological Science 37 (11), 2775-2787. 
Radivojević M. 2015, Inventing Metallurgy in Western Eurasia: a Look through the Microscope Lens, Cambridge Archaeological Journal 25, 321-338.

Radivojević M. \& Rehren T. 2016, Paint It Black: The Rise of Metallurgy in the Balkans, Journal of Archaeological Method and Theory 23 (1), 200-237.

Radivojević M. \& Grujić J. 2017, Community structure of copper supply networks in the prehistoric Balkans: An independent evaluation of the archaeological record from the $7^{\text {th }}$ to the $4^{\text {th }}$ millennium BC, Journal of Complex Networks, 1-19.

Schmidt R. R. 1945, Die Burg Vučedol, Zagreb.

Sterud E. L. \& Sterud A. K. 1974, A quantitative analyses of the material remains, Wissenschaftliche Mitteilungen des Bosnisch-Herzegowinischen Landesmuseums IV, Sarajevo, 155-355.
Težak-Gregl T. 2006, Eneolitik, in: S. Mihelić (ed.), Trgovina i razmjena u pretpovijesti, Arheološki muzej u Zagrebu, Zagreb, 33-37.

Truhelka Ć. 1906, Prehistorijski nalazi u Bosni i Hercegovini, Glasnik Zemaljskog muzeja u Bosni i Hercegovini XVIII/2, Sarajevo, 117-127.

Truhelka Ć. 1907, Prehistorijski nalazi u Bosni i Hercegovini, Glasnik Zemaljskog muzeja u Bosni i Hercegovini XIX/1, Sarajevo, 57-75.

Žeravica Z. 1993, Äxte und Beile aus Dalmatien und anderen Teilen Kroatiens, Montenegro, Bosnien und Herzegovina, Prähistorische Bronzefunde, IX/18, Stuttgart. 